Taylor C. Sherman

Department of International History

London School of Economics and Political Science

t.c.sherman@Ise.ac.uk

\title{
Education in Early Postcolonial India: Expansion, Experimentation and Planned Self-Help ${ }^{1}$
}

\section{Abstract}

After independence India's leaders, including its first Prime Minister, Jawaharlal Nehru, committed the country to democracy with universal franchise and to pursuing a socialistic pattern of society. As part of these interlocking projects, it was widely recognised that India's educational systems needed reform. However, with scarce resources, Indian policy-makers faced the dilemma of whether to improve the existing system, which served a narrow, urban elite, or expand it to the entire population, as the Constitution promised they would. This overview of education policy in the first two decades after 1947 finds that at the Centre, Indian planning did not monopolise control over education. Rather, India's was a socialism of scarcity, which relied on self-help efforts by the people to build the institutions of the welfare state. However, by relying on communities to use their own resources to build local schools, this DIY socialism entrenched existing inequalities.

\section{key words: Universal Education, Planning, Community Development, Socialism, Jawaharlal Nehru}

Although the history of education in colonial India has become a vibrant field, and there have been a good number of sociological studies of education in India in the past forty years, we know relatively little about education in the two decades after independence. ${ }^{2}$ This bird's eye survey of the field attempts to illuminate the outlines of formal ${ }^{3}$ education in postcolonial India, and suggests some areas for further research. Although it was a common rhetorical trope of the period to declare that free India required a new education system, many of the ideas and debates about education after 1947 had been developed in the years before independence. ${ }^{4}$ In part because of this continuity, the period after 1947 can be characterised, first of all, as experimental. From the Centre in New Delhi all the way down to individual institutions, Indians were experimenting with new forms of organisation and novel curricula. Rather than embarking upon a radical change of programme, Indians seemed to be searching for one. The next defining feature after 1947 was expansion. From the heights of government, it was recognised that an educated population was essential to the success of India's democracy and its economy. From below, there was hunger, not unanimous, but widespread and growing, to educate children. However, with limited resources to hand, governments seemed to face

\footnotetext{
${ }^{1}$ I am grateful to Arathi Sriprakash for comments on an early draft of this article, and to the anonymous reviewers at the journal for their constructive criticism.

${ }^{2}$ Recent surveys of the field include: Catriona Ellis, 'Education for All: Reassessing the Historiography of Education in Colonial India' History Compass, 7:2, 363-375; Tim Allender, 'Understanding Education and India: New Turns in Postcolonial Scholarship' History of Education, 39:2 (2010), 281-288; Barnita Bagchi, 'Connected and Entangled Histories: Writing Histories of Education in the Indian Context', Paedagogica Historica 50:6 (2014), 813-821.

${ }^{3}$ Nita Kumar takes a wonderfully expansive view of what constitutes education, but this article adopts a narrower definition. Nita Kumar, Lessons From Schools: A History of Education in Benares (Thousand Oaks, CA: Sage, 2000).

${ }^{4}$ This finding is in line with other research on the period. Taylor C. Sherman, William Gould and Sarah Ansari, 'Introduction' in Taylor C. Sherman, William Gould and Sarah Ansari (eds.) From Subjects to Citizens: Society and the Everyday State in India and Pakistan, 1947-1970 (New Delhi: Cambridge University Press, 2014), 1-9.
} 
a choice between providing education extensively for as many children as possible, but at a lower quality, and providing high-quality education to a select few. Policy makers thought they had landed on a solution to this conundrum when they hit upon the idea of village self-help.

The apparent centrality of self-help to education policy after independence helps us cast a new light on postcolonial India's socialism. It is widely assumed in the scholarship that independent India had a centralising state, with almost limitless ambitions. ${ }^{5}$ It is said that India's first Prime Minister, Jawaharlal Nehru, needed a strong state to pursue his vision of socialism in India. These assumptions, combined with the paucity of sources for this period, have prompted scholars to turn to the selected works of great men, whether Nehru or the successive Union Ministers of Education, Abul Kalam Azad (1947-55), Kalu Lal Shrimali (1955-63), or Mahommedali Currim Chagla (1963-66) to begin to flesh out India's postcolonial history. ${ }^{6}$ Equally, historians have tended to look for moments of rupture in central initiatives such as the successive Five-Year Plans. As such, it is conventional to regard the Second Plan (1957-1962) as a turning point, at which Nehru was able to fully elaborate his vision of a socialistic society for India.

However, the evidence from the history of education policy suggests a rather different dynamic was at play. Many functions that might be regarded as central to building a socialistic system, including education, had been devolved to provincial governments in the twilight of the Raj. After 1947 provinces - now states - retained autonomy over education, because independent India incorporated many features of the 1935 Government of India Act into its Constitution. The great men in Delhi, therefore, simply did not have command over what happened in the state governments, let alone in individual schools. Moreover, the Centre never provided sufficient vision or funding for large-scale, top-down projects. Instead, states, cities, districts and villages were encouraged to develop and fund their own programmes for education. As a whole, the Centre tended to respond to pressures from below, rather than to monopolise policy-making at the top. Crucially, this bottom-up socialism, which was designed to mobilise local resources, was likely to exacerbate India's inequalities.

\section{Ideas about education after 1947: consensus and debates}

When India gained independence in 1947 Indians who thought about education had developed a critique of the existing system, and shared ideals about what education ought to be. There was a consensus that the system India had inherited was unsuited to the needs of the hour. When they surveyed the field, Indian educationalists and policy makers found India's educational structures vastly under-served the public. In 1951, only $42.6 \%$ of eligible children attended primary school. ${ }^{7}$ This already derisory figure obscured bigger failings. At roughly the same time, for every one hundred boys at school, only thirty girls were enrolled, meaning across the nation only $1.3 \%$ of girls were in education. ${ }^{8}$ There were large differences between India's states in terms of what facilities

\footnotetext{
${ }^{5}$ a more recent statement along these lines is Uday Singh Mehta, 'The Social Question and the Absolutism of Politics' http://www.india-seminar.com/2010/615/615_uday_s_mehta.htm

${ }^{6}$ S. Irfan Habib, 'Maulana Abul Kalam Azad and His Ideas about the National Education System', Contemporary Education Dialogue 12:2 (2015), 238-257. Women, including Durgabai Deshmukh and Hansa Mehta, to name but two, were at the forefront of thinking about education at the Centre; there are no studies of education in India that turn to these women as sources.

7 Sohan Singh, 'A Review of Work Done in Eradicating Illiteracy in India' (ed.), Seminar in Eradication of illiteracy: UNESCO's Contribution to the World Programme with special reference to India. (New Delhi: Cou ncil for Social Development, India International Centre, 1966), 26-42, at 26.

${ }^{8}$ Report of the National Committee on Women's Education, (New Delhi: Government of India Press, 1959), 181.
} 
were provided for education. There were a group of states that tended to educate more children to a higher level. These included Madras (later Tamil Nadu and Andhra Pradesh), Bombay (later Maharashtra and Gujarat), Kerala, and Delhi. Those that did not perform as well included Bihar, Jammu \& Kashmir, Madhya Pradesh, Orissa, Rajashtan, and Uttar Pradesh. ${ }^{9}$ Still, a breakdown according to states does not capture inequality within them. Whereas most of India's population lived in rural areas, most of its educational facilities were in cities. As a whole, education before 1947 had tended to neglect the general population in rural areas, especially Scheduled Castes, Scheduled Tribes and women.

If structures were lacking, education methods in India were no more impressive. In its report from 1953, The Secondary Education Commission iterated typical complaints from the era. The system was:

too bookish and mechanical, stereotyped and rigidly uniform and did not cater to the different aptitudes of the pupil... Nor did it develop those basic qualities of discipline, cooperation and leadership which were calculated to make them function as useful citizens. The stress on examinations, the over-crowded syllabus, the methods of teaching, and lack of proper material amenities tended to make education a burden rather than a joyous experience to the youthful mind. ${ }^{10}$

In part because of the uninspired methods used, India's schools did not attract enough of 'the right type' of teachers. And, as one report from 1952 despaired, 'The standard of instruction...is generally poor and sometimes shockingly low'. ${ }^{11}$

Finally, India's nationalists had developed a critique of the foreign content of the curriculum developed under colonial rule. D.S. Kothari, the eminent physicist and educationalist, and head of the University Grants Commission, offered a familiar lament: Under the British, 'The centre of gravity of India's intellectual life...moved away from India...' as schools taught the Western Canon instead of Indian classics. 'The system turned out "educated" Indians, but without roots in their soil and culture... It provided "English education" but smothered the souls. ${ }^{12}$ The result was an educational system that had become 'removed from the needs of the community' in order to 'service its alien masters' ${ }^{13}$

This assessment could only spring from a wilful amnesia about Indian involvement in education in the recent past. While there is no doubt that the British had sought to shape Indian education to suit the needs of the empire, ${ }^{14}$ it had been government policy since 1854 that private Indian initiatives in education ought to be given full encouragement. This sentiment was repeated by the Hunter

\footnotetext{
${ }^{9}$ Pandit Gopesh Kumar Ojha, Progress of Compulsory Education in India (1951-1966) (New Delhi: Universal Book and Stationery Co., 1966), chs.9-11.

${ }^{10}$ Report of the Secondary Education Commission. (New Delhi: Government of India Press, 1953), 17.

${ }^{11}$ K. Saiyidian, JP Naik, and S Abid Husain, Compulsory Education in India. (New Delhi: Universal Book and Stationery Co., 1952), 41.

12 D.S. Kothari, Education, Science and National Development. (London: Asia Publishing House, 1968), 3

${ }^{13}$ Ministry of Community Development and Co-operation, Three Basic Institutions (Faridabad: Government of India Press, 1959), 11.

${ }^{14}$ e.g. Gauri Viswanathan, Masks of Conquest: Literary Study and British Rule in India (New York: Columbia University Press, 1989); Krishna Kumar, Political Agenda of Education: a Study of Colonialist and Nationalist Ideas (New Delhi: Sage, $2^{\text {nd }}$ edn, 2005), Part I; Sanjay Seth, Subject Lessons: the Western Education of Colonial India (Durham, NC: Duke University Press, 2007).
} 
Commission in 1882. ${ }^{15}$ Though movement had been slow in this direction, provincial governments eventually established a system of grants-in-aid to private institutions, which came to account for a large number of educational establishments in India, especially for women. For example, at independence, out of 21,479 institutions for women at all levels, 13,635 were private, with nonofficial institutions particularly prominent in higher and vocational education. ${ }^{16}$ Of course, not all of these private schools were run by Indians. Christian missionaries had played a significant role in education during the colonial period. ${ }^{17}$ Still, Indian experiments with education were central to India's religious revivalist and nationalist movements, as they competed with one another and with the Christians to shape young Indian minds and souls. ${ }^{18}$

In addition to these private initiatives, education had been the responsibility of elected provincial governments since the 1919 Government of India Act. While they were constrained in important respects, especially fiscally, provincial and local governments led by Indians were the dominant force in education policy in the three decades before independence. ${ }^{19}$ Indian princes, too, had taken to education, designing and funding important experiments in schooling in the last decades of the Raj. ${ }^{20}$ That Indians were starting from scratch after the disruptions of the colonial past was a trope in the discourse on education in this period, useful to the extent that it could give the impression that Indians were making a radical break from the past and so needed new thinking on the subject.

Indians interested in the subject also had some shared ideals about what education ought to be. Firstly, by the middle of the 1940s there was a consensus that education at the primary level ought to be free, universal and compulsory. This had been accepted by Indian elites in the inter-war period, as many provinces had enacted compulsory education legislation under Dyarchy. ${ }^{21}$ Not to be outdone, the princely states passed similar acts, so that by 1950 'almost every state in the union' already had laws on the books for compulsory education. ${ }^{22}$ With the Sargent Report on post-war education, published in 1944, the Raj came around to the idea of free, universal education for all six to fourteen year olds. Therefore, when Article 45 was added to the section of India's Constitution on the directive principles of state policy, and promised: 'The State shall endeavor to provide, within a period of ten years from the commencement of this Constitution, for free and compulsory education

\footnotetext{
${ }^{15}$ On the Hunter Commission see, Tim Allender, Ruling through Education: The Politics of Schooling in the Colonial Punjab (Elgin, IL: New Dawn Press, 2006), ch.8.

${ }^{16}$ Report of the Committee to Look into the Causes for Lack of Public Support Particularly in Rural Areas for Girls Education and to Enlist Public Cooperation. (New Delhi: Ministry of Education, Government of India, 1965), 7.

${ }^{17}$ Hayden J.A. Bellenoit, Missionary Education and Empire in Late Colonial India, 1860-1920 (Abingdon: Routledge, 2015).

${ }^{18}$ Kumar, Political Agenda of Education, Part II; Francis Robinson, Gail Minault, Madhu Kishwar, 'Arya Samaj and Women's Education: Kanya Mahavidyalya, Jalandhar', Economic and Political Weekly 21:17 (1986), WS9WS13+WS15-WS24; Ali Riaz, 'Madrassah Education in Pre-Colonial and Colonial South Asia', Journal of Asian and African Studies, 46:1 (2011), 89-66; John Pridmore, 'The Poet's School and the Parrot's Cage: the Educational Spirituality of Rabindranath Tagore', International Journal of Children's Spirituality 14:4 (2009), 355-367; Vicki Langohr, 'Colonial Education Systems and the Spread of Local Religious Movements: The Cases of British Egypt and Punjab', Comparative Studies in Society and History 47:1 (2005), 161-189.

${ }^{19}$ e.g. Catriona Ellis, 'Children and Childhood in the Madras Presidency, 1919-1943' (University of Edinburgh, PhD, 2016).

${ }^{20}$ On Baroda and Mysore, Manu Bhagavan, Sovereign Spheres: Princes, Education and Empire in Colonial India (Delhi, Oxford University Press, 2003); on Hyderabad, Kavita Datla, The Language of Secular Islam: Urdu Nationalism and Colonial India (Honolulu, University of Hawaii Press, 2012).

${ }^{21}$ Saiyidian, Naik, and Husain, Compulsory Education in India, 33-4.

22 Ibid. 34
} 
for all children until they complete the age of fourteen years' the move was ambitious practically but not conceptually.

Another point of agreement that had emerged since the early decades of the twentieth century was the idea that primary education ought to be in the mother-tongue of the child. Indeed, in 1956, article 350A was added to the constitution to the effect that states ought to provide mother-tongue instruction at primary school. However, Indians spoke some 1600 different mother-tongues, ${ }^{23}$ making this simple idea an immense challenge in practice. Instead, mother-tongue instruction became a euphemism for education in the regional language, or in the majority language of areas where the population did not speak the official language of the state. This was not only because senior policy makers decided that truly abiding by this prescription was not practicable; these men and women had imbibed colonial epistemologies which deemed only around a dozen of India's languages to be sophisticated enough to be suitable for education. ${ }^{24}$

Unsurprisingly, education was also expected to serve the nation. It was unanimously agreed that for a democracy with universal franchise to function properly, voters would need to be educated. Once again expressing a widely-held view, the Secondary Education Commission noted that schools should provide 'training for democracy' including a balance between 'social virtues, intellectual development and practical skill'. ${ }^{25}$ As India's democratic structures evolved, so did the expectations of education. Thus, by the late 1950s, the success of the system of village government, Panchayati Raj, was tied to the education of the population. ${ }^{26}$ Education was also expected to feed into India's economic development, providing the necessary skills to build self-sufficiency. It was also deemed to be central to social reform, cultivating the 'right individual and collective habits' in every sphere of life from hygiene to leisure activities. ${ }^{27}$ Dreams of fostering national cohesion were also heaped upon schools, colleges and universities. ${ }^{28}$ In sum, it was hoped that a reformed education system would do nothing less than, 'build up a new, vigorous, self-reliant, resourceful and democratic society. ${ }^{29}$

This is not to say that there were no disagreements on the subject. Policy-makers debated the question of whether to focus on quantity or quality. In other words, should the Centre and the States focus on providing education for all, 'of a rather short duration and, if necessary, mediocre quality'? Or should governments put their resources into improving quality at existing institutions, even if this meant turning a blind eye to the Constitutional directive to provide education for all? ${ }^{30}$ In

\footnotetext{
${ }^{23}$ On multilingualism in India, see E. Annamalai, Managing Multilingualism in India: Political and Linguistic Manifestations. (New Delhi: Sage, 2001).

${ }^{24}$ Taylor C. Sherman, Muslim Belonging in Secular India: Negotiating Citizenship in Postcolonial Hyderabad (Cambridge: Cambridge University Press, 2015), 160-161; Farina Mir, 'Imperial Policy, Provincial Practices: Colonial Language Policy in Nineteenth Century India', Indian Economic and Social History Review, 43 (2006), 395-427 at 413-4.

${ }^{25}$ Report of the Secondary Education Commission. (New Delhi: Government of India Press, 1953), 5

${ }^{26}$ C.D. Deshmukh, Free But Fettered - the Illiterate Citizen (Bombay: Forum for Free Enterprise, 1970), 6

27 S.C. Dutta, and Helen Kempfer, Social Education in Delhi: Report of a Research Study Undertaken by the Indian Adult Education Association. (New Delhi: Indian Adult Education Association, 1960).

${ }^{28}$ Report of the Committee on Emotional Integration (New Delhi: Government of India, Ministry of Education, 1962).

${ }^{29}$ Government of Maharashtra, Report of the Basic Education Review Committee (Bombay: Government Central Press, 1962), 62.

${ }^{30}$ Saiyidian, Naik, and Husain, Compulsory Education in India, viii.
} 
a country with huge needs and limited resources, the choice between quantity and quality posed a dilemma in nearly every sector of the development agenda. ${ }^{31}$

A second debate was over the question of whether to replace the existing curriculum with Basic Education. Basic Education was the nationalist curriculum developed first by Mahatma Gandhi and Zakir Hussain, and then in the laboratories of the Congress-run Provincial Ministries between 1937 and 1939. Drawing on insights from global trends in education, such as the work of Maria Montessori, Friedrich Fröbel and John Dewey, this was education through activities, rather than simply learning at a desk. In India, this activity-based education was also aimed at building selfsufficient communities and 'creating eventually a social order free from exploitation and violence.'32 To this end, the main focus was 'productive, creative and socially useful work in which all boys and girls may participate, irrespective of any distinction of caste or creed or class' ${ }^{33}$ This work mainly took the form of craft, especially spinning, papermaking or gardening. This kind of education, it was hoped, would give children 'the right kind of training in useful habits and attitudes like purposeful application, concentration, persistence and thoughtful planning. ${ }^{34}$ More importantly, it was imagined that it would instil in all children, 'respect and love for all socially useful work' especially for manual labour. ${ }^{35}$ Craft work was not the only activity; students were to learn through 'correlation' of knowledge with their natural or social environment. The Government of India's Syllabus for Basic Schools published in 1950, provided a number of examples:

while cleaning the school the child learns the simple principles of hygiene. His village pond initiates him into the science of Botany and Zoology. Again while spinning, before he can report how many yards of yarn are produced...or what is the count of the yarn that has been spun, he should learn counting and simple operations of arithmetic. ${ }^{36}$

For all the high ideals of Basic Education, it was pursued unevenly. In Uttar Pradesh and Bombay/Maharashtra the governments converted schools en masse to the Basic Education curriculum, but in other states it was relatively neglected, and some policy makers regarded it as nothing more than a fad. ${ }^{37}$

The final area of contention was the language of instruction. Although there was a consensus that primary education ought to be in the mother tongue, there was no agreement on what to do about the higher levels of education. The University Education Commission, chaired by Sarvepalli Radhakrishnan reported in 1950 that, 'No other problem has caused greater controversy' than the question of the medium of instruction. ${ }^{38}$ And the question remained one of the more combustible

\footnotetext{
${ }^{31}$ On the balance struck in agriculture, see Taylor C. Sherman, "From "Grow More Food" to "Miss a Meal": Hunger, Development and the Limits of Postcolonial Nationalism in India, 1947-1957' South Asia: Journal of South Asian Studies 36:4 (2013), 571-588. On the discourse of India as a 'needy nation', see Srirupa Roy, Beyond Belief: India and the Politics of Postcolonial Nationalism (New Delhi: Permanent Black, 2007), ch.3. 32 Ministry of Education and Scientific Research, Government of India, The Concept of Basic Education. (New Delhi: Government of India Press, 1956), 2

33 Ibid., 2.

${ }^{34}$ Ibid., 4.

35 Ibid., 2.

${ }^{36}$ Ministry of Education, Government of India, Syllabus for Basic Schools. (New Delhi: Government of India, 1950), 5.

37 Ojha, Progress of Compulsory Education in India (1951-1966) 323.

${ }^{38}$ Report of the University Education Commission (Simla: Government Press, 1950), 305.
} 
areas of education policy in this period. ${ }^{39}$ For the most part, India's educationalists agreed on the nature of the problems and on many, if not all, of the solutions. The question was how to go about reform, and, more importantly, how to fund it.

\section{From the Centre: Planned Neglect}

The first decades after independence were supposedly the era of The Plan. Wherever committees and commissions looked they found that a 'planned approach' was the way forward. ${ }^{40}$ In some respects, India was simply following global trends, which saw planning as the key to fostering development in the middle decades of the twentieth century. ${ }^{41}$ At the same time, planning was seen as a way of avoiding waste in a country with very few resources. This was equally true in the field of education, where it was widely held that the way forward for governments was to make considered judgments about how to allocate resources only after careful study. Early scholarship on planning tended to privilege the state, assuming it monopolised initiative in those areas of policy that were planned. However, more recent histories have tended to stress the limitations of planning. ${ }^{42}$ When one examines plans for education, it is evident that the Centre had very limited ambitions, and that it never sought to dominate the field. Instead, pressure from below prompted the Centre to expand its remit, but it did so while avoiding financial responsibility for education.

If one were to judge education policy by the Government of India's five-year plans, central planners seem to have moved from a selective approach to an extensive one over the first fifteen years of planning. The First Plan laid out its vision of a 'national system of education', which included universal education from ages 6-14, twenty per cent enrolment in secondary education, and ten per cent attending university, plus technical education and other odds and ends. It was estimated that a fully functional educational system of that kind would cost Rs 400 crores annually. ${ }^{43}$ However, the first plan allocated around Rs.30 crores per annum to education. This is because the Government of India limited its own initiatives to funding 'experiments' ${ }^{44}$ in education aimed at improving quality. For example, the Centre urged that in each state 'at least one group of model basic institutions' ought to be opened to develop improved methods for Basic Education. ${ }^{45}$

In historical lore, the second plan was the moment at which Nehru and Mahalanobis set out their vision for a more socialistic pattern of society. ${ }^{46}$ More recent historiography, however, has begun to challenge the idea that the Second Plan was the apotheosis of Nehruvian planning. ${ }^{47}$ Indeed, in

\footnotetext{
${ }^{39}$ Austin, Granville, 'Language and the Constitution: the Half-Hearted Compromise', A. Sarangi (ed.), Language and Politics in India. (New Delhi: OUP, 2009), 41-92; Kaviraj, Sudipta, 'Writing, Speaking, Being: Language and the Historical Formation of Identities in India' in Ibid., 312-350; Sarangi, Asha, 'Introduction: Language and Politics in India' in Ibid, 1-38.

${ }^{40}$ Medha Kudaisya, '"A Mighty Adventure": Institutionalising the Idea of Planning in Post-colonial India, 194760', Modern Asian Studies 43:4 (2009), 939-978.

${ }^{41}$ David Ekbladh, The Great American Mission: Modernization and the Construction of an American World Order. (Princeton, NJ: Princeton UP, 2010), 1-4.

42 Vivek Chibber, Locked in Place: State-Building and Late Industrialisation in India. (Princeton, NJ: Princeton University Press, 2008); Kudaisya, 'A Mighty Adventure'.

${ }^{43}$ Government of India, First Five Year Plan, ch. 33.6

http://planningcommission.nic.in/plans/planrel/fiveyr/welcome.html (accessed, 8 November 2017).

${ }^{44}$ Ibid., ch. 33.11

45 Ibid., ch. 33.20

${ }^{46}$ e.g. Partha Chatterjee, 'Development Planning and the Indian State', Partha Chatterjee (ed.), State and politics in India. (Delhi: OUP, 1997), 271-297; Francine R. Frankel, India's Political Economy: the Gradual Revolution, 1947-77. (Princeton, NJ: Princeton University Press, 1978), ch.4.

${ }^{47}$ Kudaisya, 'A Mighty Adventure'
} 
terms of education, the Second Plan was no watershed. Although the Plan noted the important contribution of education to 'economic progress', putting resources into education was still not a priority. Accordingly, annual funding from the Centre rose only to around Rs. 50 crore. ${ }^{48}$ This was about half of what the government was spending on large and medium sized industry in the Second Plan, and only a little bit more than it was spending on roads. This modest rise for education came at a time when the overall outlay of the plan rose from Rs 2069 crores to Rs 4800 crores between the two plans. ${ }^{49}$

It was with the Third Plan (1962-67) that the Government of India finally set out to fulfil the Constitutional directive to provide universal, free education to all children up to the age of fourteen, at least partially. The Plan aimed to enrol 'about 90 per cent of the boys and about 62 per cent of the girls' in primary education, that is, up to age eleven, by $1966 .^{50}$ To do this, provision would have to be made to establish a school within walking distance of children's homes and to employ more teachers. Although the Centre increased its annual budget for education to almost Rs 110 crores, this was around one quarter of the cost of a national system of education as it had been estimated in 1951. After a decade of population rises and inflation, the total sum would surely have been much higher by the start of the Third Plan.

Even before the end of the Third Plan, however, the Centre dropped this ambition. Following the war with China in 1962 and the declaration of a national emergency, the Centre shifted as much funding as it could to the military and to defence industries. This laid waste to plans to provide primary schooling for every child, as most states were compelled to reduce expenditure on education. By 1964, therefore, M.C. Chagla, the Union Minister for Education, was urging the nation to once again to focus on 'consolidation and quality', as opposed to expansion. In April 1964, he set out his vision for creating institutions that represented the 'peaks of excellence' all over the country, 'which would be a sort of beacon lights to all the other institutions fired with ambition to attain the same high position. ${ }^{51}$ This swing away from the pursuit of universal education was confirmed when war broke out with Pakistan in 1965. Thus, the Report of the Education Commission (1964-66), chaired by D.S. Kothari, urged educators and policy makers to focus on eliminating 'wastage' and improving quality. ${ }^{52}$

On the face of it then, the Central government planned to neglect education. Although the Constitution had set the goal of providing universal education up to the age of fourteen within ten years, the Centre only planned to educate children up to the age of eleven, and that, too, belatedly and only for a brief moment in the Third Plan. More to the point, the central planners never provided sufficient funds to meet even these more circumscribed ambitions. Planning, at least at the Centre, seems to have amounted to recognising the scale of the problem, and then moving on to more important things.

That being said, the central planners did not have a monopoly on policy or funding, even at the national level. International aid agencies may have influenced the direction of thinking on education, though we do not know enough about the modalities of how these functioned in India. Until the

\footnotetext{
${ }^{48}$ Government of India Second Five Year Plan (1957-1962), Ch.23.2.

http://planningcommission.nic.in/plans/planrel/fiveyr/welcome.html (accessed, 8 November 2017).

49 Ibid., ch.3.2.

${ }^{50}$ Government of India, Third Five Year Plan, 1962-1967, Ch.29.14.

http://planningcommission.nic.in/plans/planrel/fiveyr/welcome.html (accessed, 8 November 2017).

${ }^{51}$ Ojha, Progress of Compulsory Education in India (1951-1966), 227-8.

52 Ministry of Education, Government of India, Report of the Education Commission (1964-66). (New Delhi:

Government of India Press, 1966), 152.
} 
1970s UNESCO was the main international institution involved in educational development. At the same time, Indians were involved in UNESCO: the prominent nationalist, campaigner for women's rights and educationalist, Hansa Mehta, served on the Executive Board of UNESCO. Although there are intriguing hints in this direction, further research might reveal how India's involvement with UNESCO shaped both India and UNESCO. ${ }^{53}$ In addition, we know that UNICEF was important in the mid-day meal scheme in Orissa, for which the UN agency provided aid in the form of milk powder. We only have hints at the 'complex collaborations' between India and these international agencies, but these hints add force to the idea that the central planners ought not to be the starting and ending point from which we try to understand the history of education in India. ${ }^{54}$

\section{From Below: Impetus and Inspiration}

Looking at education policy from the other direction, pressure from below was almost constant, if not always uniform and consistent. Almost as soon as the First Plan got under way, a Conference of Education Ministers protested, 'it was not enough for the Government of India to render assistance for schemes aiming at qualitative improvement only. ${ }^{\prime 5}$ These state-level ministers insisted that the Centre put efforts into expansion as well.

Indeed, in the states, programmes to expand access to primary education outpaced thinking at the Centre. Before 1947, Madras had had one of the most progressive and extensive education programmes in British India. ${ }^{56}$ After independence, it restarted some programmes that had been discontinued due to the war, including a midday meal scheme, re-launched in 1956, which fed $1.3 \mathrm{~m}$ children. ${ }^{57}$ Madras was also at the forefront of an innovative scheme designed to harness that putative urge of the people to build their own schools, the School Improvement Conference. At these conferences communities were mobilised to contribute the necessary infrastructure and equipment to start or improve a local school. Starting with a pilot project in February 1958 at Kadambathur in Dangleput District, within three years, 133 such conferences had been conducted. They collected contributions amounting to Rs. 4 crores, amassing everything from construction and electrification of buildings to provision of books, musical instruments and first aid materials. ${ }^{58}$

Elsewhere, Bombay, Madhya Pradesh, Uttar Pradesh and Delhi experimented with the conversion of ordinary schools to the Basic Education curriculum in the first half of the 1950 s. ${ }^{59}$ Rajasthan, Bihar and Orissa set up enrolment drives in 1958 and 1959. Orissa introduced a midday meal scheme as well. With the help of milk powder provided by UNICEF and donations from local communities, the

\footnotetext{
${ }^{53}$ Rosie Peppin Vaughan, 'Complex Collaborations: India and International Agendas on Girls' and Women's Education, 1947-1990', International Journal of Educational Development 33 (2013), 118-129; Jason A. Kirk, India and the World Bank: the Politics of Aid and Influence. (London: Anthem Press, 2010), ch.1.

${ }^{54}$ The term is Peppin Vaughan's. Scholarship in an older analytical vein tended to emphasise the top-down character of international aid, e.g. Joseph Watras, 'UNESCO's Programme of Fundamental Education, 1946-59', History of Education, 39:2 (2010), 219-237.

55 Ministry of Education, Government of India, Basic Education in India During the First Five-Year Plan (New Delhi: Government of India, Ministry of Education, 1958), 3.

${ }^{56}$ Catriona Ellis, 'Children and Childhood in the Madras Presidency, 1919-1943', chs.1-4.

${ }^{57}$ Shrimali, Kalu Lal, Education in Changing India. (London: Asia Publishing House, 1965), 36-7.

${ }^{58}$ Ministry of Education, Government of India, National Seminar on Compulsory Education. (New Delhi: Government of India Press, 1961), 37-8.

${ }^{59}$ Ministry of Education, Government of India, Basic Education in India During the First Five-Year Plan (New Delhi: Government of India, Ministry of Education, 1958), for statistics see 51-54. See also, Government of Maharashtra, Report of the Basic Education Review Committee.
} 
scheme fed one lakh students in fourteen districts of the eastern state. Perhaps the most successful state was Kerala, which, by 1962, had full enrolment in primary schools. ${ }^{60}$

Thus, in spite of the Centre's rather muted support, the overall picture can be summarised in one word: expansion. There were several facets to this. First, in terms of absolute numbers, primary school attendance certainly broadened in this period. In $195142 \%$ of children attended primary school. By 1966 , this had risen to $78.5 \% .{ }^{61}$ Still, this was hardly an unqualified success, as 'wastage' remained a problem: only around half of students who began primary school reached Class IV in 1965-6. ${ }^{62}$ In the same period, enrolment in secondary education expanded four-fold for lower secondary schooling, and five-fold in higher secondary institutions. ${ }^{63}$ These numbers, however, hide inequalities between boys and girls, between high castes and low, and between urban and rural areas, which will be discussed below.

Second, there was an expansion in the norms concerning the number of years of education a child ought to attend. At independence, the focus was on eight years of education, from 6-14. But in the first two decades after 1947, education on either side of these core years expanded. Pre-primary education grew quite dramatically. In 1951 there were 303 institutions providing pre-primary education to around 28,000 children. Fifteen years later, 3500 pre-primary schools catered to 250,000 children, while another 20,000 Balwadis served 600,000 in rural areas. ${ }^{64}$ Although the number of children attending these pre-schools was relatively tiny, by the middle of the 1960s it was recognised the pre-schools did important preparatory work for formal education. ${ }^{65}$ On the other side of primary school, whereas in the 1940s, secondary school was seen as something for the 'select few', by the 1960s, this assumption had 'ceased to be valid' ${ }^{66}$ In the states, India had witnessed an increase in the provision of secondary education, as governments and private providers responded to what the Kothari Commission called, with a mix of awe and paternalism, 'hunger' in the cities and 'awakening' in rural areas. ${ }^{67}$ University education, too, blossomed in this period. India had 20 universities in 1947, but by 1968 there were 70 universities and another 18 institutions with university status in the country. ${ }^{68}$

By the 1960s educators and policy-makers were at least paying lip-service to the idea of life-long learning, or as the Union Education Minister, K.L. Shrimali, told an Adult Education Conference in 1960 rather grimly, 'The process of education must continue from childhood until death' ${ }^{69}$ Indeed, with literacy rates in the population as a whole at around $16 \%$ the early $1950 \mathrm{~s},{ }^{70}$ policy makers repeatedly acknowledged the necessity of providing adult education as a means of making democracy work in the new nation. Moreover, adult education was expanded beyond just literacy. Renamed 'Social Education', it included farming methods, crafts, sanitation, as well as social and cultural activities. The idea was to inculcate the 'right individual and collective habits' even in the segments of the population who did not attend formal schooling. ${ }^{71}$ Indeed, 'adult' in this context had

\footnotetext{
${ }^{60}$ Ojha, Progress of Compulsory Education in India, 266.

${ }^{61}$ Singh, 'A Review of Work Done in Eradicating Illiteracy in India' 26.

${ }^{62}$ Report of the Education Commission (1964-66), 151.

63 Ibid., 166-7.

64 Ibid., 149.

65 Ibid.

${ }^{66}$ Report of the Education Commission (1964-66), 147.

67 Ibid., 90-1.

${ }^{68}$ Kothari, Education, Science and National Development, 5.

${ }^{69}$ Shrimali, Education in Changing India, 17.

70 Singh, 'A Review of Work Done in Eradicating Illiteracy', 26.

${ }^{71}$ Deshmukh, Free But Fettered, 3.
} 
a rather expansive meaning, for it included anyone over the age of twelve and not in school. ${ }^{72}$ The Adult Social Education Committee, chaired by Mohanlal Saxena and reporting in 1948, hoped to half illiteracy within 5 years. ${ }^{73}$ Social education was pursued by a huge array of institutions, from Education Ministries to voluntary organisations. Some states tried to tackle the issue using the tactics of the national movement. In Maharashtra between 1961 and 1963 a Gram Shikshan Mohim sought to eradicate illiteracy from villages in the state. ${ }^{74}$ Provision may have expanded, but it could not keep pace with India's ballooning population, and the absolute number of illiterate adults continued to rise. ${ }^{75}$

\section{Experimentation and Enthusiasm}

If the overall picture is one of expansion, there were a number of more qualitative characteristics of education policy in the period that are worth exploring. The first theme of government action in this period was experimentation. In line with the scientific approach to solving India's problems, education policy was full of model schools, pilot projects, studies of effectiveness, nation-wide surveys, and other tools of mid-century practical social science. This was particularly true in the First Plan, where the centre believed 'high priority should be given to experiments and research in improved educational methods. ${ }^{76}$ But the idea that tests and trials of various kinds would eventually yield the ideal solution to India's problems was ubiquitous through to the 1960 s.

The second feature of the period was popular demand. With a few important exceptions, enrolment drives for primary education were overwhelmingly successful. These drives resembled the campaigns of the national movement. For example, the blueprint for village level enrolment drives in Orissa included processions of school children; special slogans and songs; door-to-door persuasion of parents; and mass meetings addressed by VIPs. ${ }^{77}$ These drives regularly surpassed their goals: Orissa's second five year plan set a target of enrolling 7.5 lakh boys and 2.5 lakh girls, and it achieved 9.7 lakh boys and 4.4 lakh girls. ${ }^{78}$ Madhya Pradesh had a similar experience, exceeding its targets for the third plan by more than three hundred per cent. ${ }^{79}$ Moreover, these enrolment drives created expectations in the population that state governments found it hard to resist. For example, Andhra Pradesh tried to retrench teachers after the 1962 war, but the move gave rise to 'much public resentment' and the state decided to reverse course and hire roughly five thousand more teachers in $1965-6 .{ }^{80}$

Education was, of course, a system of integrated parts, so increased demand created its own problems. Ancillary structures, institutions, services and products all had to be conjured into existence and paid for. These included teacher training and increased pay; writing, publishing and translating textbooks and other learning materials; founding, stocking and running libraries, as well as constructing schools. All of this pointed, again, to the formidable cost of building an educational system. By the end of the third plan India still only spent around three per cent of national income on education, one of the lowest rates in the world at the time. ${ }^{81}$

\footnotetext{
72 Dutta and Kempfer, Social Education in Delhi, 19.

${ }^{73}$ Singh, 'A Review of Work Done in Eradicating Illiteracy, 36.

${ }^{74}$ Ibid., 27-8.

75 Deshmukh, Free But Fettered.

${ }^{76}$ Government of India, First Five-Year Plan, ch.33.1.9

${ }^{77}$ National Seminar on Compulsory Education, 31-3.

78 Ojha, Progress of Compulsory Education, 245.

79 Ibid., 242.

80 lbid., 257.

81 Ibid., 242.
} 
Instead of state-funded initiatives, therefore, India's policy-makers put great emphasis on the resourcefulness of the people. The First Plan noted that 'the people are keen to contribute in cash, kind, labour or land' to establish educational facilities in their locality, and it urged state and central governments to 'harness this urge in the people' to build up an educational system without government funds. ${ }^{82}$ As they prepared to move towards universal primary education in the early 1960s, policy-makers at the Centre seized upon the School Improvement Conference, first pioneered in Madras, as the key to building an education system using local resources. ${ }^{83} \mathrm{In}$ fact, the larger the problem, the more the Centre seemed to expect resources to somehow bubble up from below. For example, perhaps the greatest cost in educating children was in finding buildings for schools. A National Seminar on Compulsory Education convened in 1961 estimated that to provide the schools necessary to meet the expansion proposed in the draft Third Plan would cost Rs330 crores. The Seminar called the problem 'colossal', and proceeded to decide, 'unanimously' that 'the time had now come to place the responsibility of providing school buildings squarely on the village community itself' ${ }^{84}$ In turn, the Third Plan, stressed that state responsibility for building more extensive educational facilities would have to be supplemented with 'local community effort' ${ }^{85}$ In sum, the state showed little desire to monopolise responsibility for education.

The notion that the state should not do everything was not just a matter of fiscal impossibility. More than one voice held that voluntary initiatives were morally superior. For example, the National Committee on Women's Education, chaired by Durgabai Deshmukh, argued in 1959, that services 'rendered by the State' including education, tended to become 'impersonal and static'. In contrast, the 'selfless, devoted and experienced men and women' who volunteered in the education sector had a salutary effect on schools. Voluntary effort was also good for democracy and for the economy: these undertakings gave citizens the opportunity to express their 'social idealism' and were 'more effective and speedy and economical in their undertakings.' This was absolutely part of India's socialistic project, the Committee insisted. Whereas 'the social urges of a welfare state' might require the reduction of private enterprise in trade, commerce, or industry, 'in the vital fields of social welfare activities these very urges dictate the need for the steady extension of the areas of voluntary effort. ${ }^{86}$ The Committee did recommend, however, that government ought to give financial assistance to these voluntary efforts. ${ }^{87}$

The promotion of voluntary action and self-help extended in some cases to schools themselves, some of which were pushed to fund their own upkeep through productive activities. This idea had its origin in the Wardha Scheme of Basic Education. As a means of overcoming the prohibitive costs of establishing and running them, Gandhi had suggested that schools ought to make self-sufficiency central to the learning process. The idea was that students could learn to produce cloth, paper goods, food, and other necessities, and so pay for the upkeep of their school, their teacher, and other expenses. The Conference at Wardha in 1937 where the scheme was first proposed did not endorse the idea of self-sufficient schools, however, and the debate lingered. ${ }^{88}$ Within eighteen months of independence, Education Minister, Abul Kalam Azad, decided that schools should not be

\footnotetext{
82 Government of India, First Five-Year Plan, ch. 33.8.

83 National Seminar on Compulsory Education, 12-13.

${ }^{84}$ Ibid., 12.

${ }^{85}$ Government of India, Third Five year Plan, Ch.29.21

${ }^{86}$ Report of the National Committee on Women's Education (1959), 143

87 Ibid., 151.

${ }^{88}$ T.S. Avinashilingam, Understanding Basic Education: Ministry of Education and Scientific Research, Government of India, 1954), 4-6.
} 
required to meet their own expenditure..$^{89}$ Nonetheless, from the first five year plan through to 1968 there were voices that called for schools to be productive. Thus, the first plan urged schools to engage in 'economic activities' in order to 'recover at least a part of the recurring expenditure'.$^{90} \mathrm{At}$ the other end of the period, D.S. Kothari, head of the University Grants Commission opined, 'It is becoming increasingly clear that education on a large scale, and with any pretence to quality, can be supported only if education itself makes a direct contribution to national productivity. ${ }^{91}$ This was not mere rhetoric. In Maharashtra, where Basic Education was pursued with more enthusiasm, schools were subject to a quota system for the production of yarn and cloth. ${ }^{92}$ It turned out, however, that these schemes had been over-optimistic about the quality of the products, which, it transpired, were hard to sell. ${ }^{93}$

The result was wide and increasing variety in terms of the quality, quantity, structures and methods of provision. ${ }^{94}$ At the state level, enrolment varied widely, from Kerala, where all children attended primary school, to Bihar, UP, Jammu and Kashmir, MP and Rajasthan, where enrolment hovered around $50 \%$ for all children, with higher figures for boys and lower ones for girls. ${ }^{95}$ Some states promoted Basic Education, others ignored it. Everywhere voluntary organisations and private institutions remained strong players in education, adding further variety to curricula and educational methods.

\section{Local Initiative, National Inequality}

As the Centre came round to the idea of supporting universal primary education, it simultaneously promoted the idea that states ought to adopt the self-help model developed in the Madras School Improvement Conference to expand education. Inevitably, this would have added immense variety to the content, structure and quality of the school experience. The logical conclusion to draw is that reliance on local initiative, especially local funds, must have increased inequality.

This is most apparent when one looks below the national or state-level averages to women, Dalits, Adivasis, and other marginalised communities. Policy makers and elites had a tendency to regard certain 'educationally backward' communities as obstacles to the expansion of education. Thus, it was a common refrain in the reports of committees and commissions that 'propaganda' was required to remove the 'prejudices' and 'apathy' from the minds of these communities. ${ }^{96}$ Although such attitudes may have been present, they were reported to be 'fast disappearing' in many areas such as Jammu \& Kashmir. ${ }^{97}$ Indeed, the fragmentary evidence that is available suggests that where funding was provided to help children of under-educated communities into school, these facilities were over-subscribed. ${ }^{98}$

\footnotetext{
${ }^{89}$ Abul Kalam Azad, 25 February 1949, in R. Kumar (ed.), Selected Works of Maulana Abul Kalam Azad, volume IV. (New Delhi: Atlantic Publishers and Distributors, 1992), 65.

90 Government of India, First Five Year Plan, ch.33.4.37

${ }^{91}$ Kothari, Education, Science and National Development, 31.

92 Government of Maharashtra, Report of the Basic Education Review Committee, 14

93 Ibid., 18.

${ }^{94}$ Report of the Education Commission (1964-66), 25

95 Ojha, Progress of Compulsory Education in India, 231-254.

${ }^{96}$ Report of the National Committee on Women's Education (1959), 183; Report of the Backward Classes Commission. (Simla: Government of India, 1955), 107.

${ }^{97}$ Report of the Committee to Look into the Causes for Lack of Public Support Particularly in Rural Areas for Girls Education and to Enlist Public Cooperation. (New Delhi: Ministry of Education, Government of India, 1965), 13.

${ }^{98}$ Report of the Backward Classes Commission, 107-110.
} 
Without discounting the importance of attitudes altogether, it is clear that the material barriers to the education of the most marginalised were tremendous. One of the main barriers to girls' education across different provinces, for example, was the need for them to work in the home, looking after younger children while older women worked in the fields. ${ }^{99} \mathrm{~A}$ similar issue arose for children in the other backward classes, where young people contributed to the family income from an early age. ${ }^{100}$ Another significant obstacle for the poorest communities was the absence of local schools for sparse and scattered rural communities. A nation-wide survey in 1957 found that almost $25 \%$ of the population, or around seventy million people, lived in habitations of less than 300 people. ${ }^{101}$ In some places this was a question of geography. For example, in Jammu \& Kashmir, the mountainous terrain meant large settlements were rare. Poor or non-existent roads meant travelling to school (or teachers travelling to these habitations) was not an option. But it was not only a matter of geography: Bihar may have been low and flat, but still had a very large number of small, scattered settlements. Providing education for these children increased the cost exponentially: while the annual cost of educating one student in Kerala was Rs31 in 1966, it was Rs116 in the inaccessible hills of the North-East Frontier Agency, the territory that would become Arunachal Pradesh. ${ }^{102}$ Individual families could send their children outside for education, but this was a costly endeavour available only to those with significant capital. Meanwhile, officials deemed pooling resources in such areas to be impractical, whether that might mean funding a peripatetic teacher, providing transportation or building hostel facilities at a central school. ${ }^{103}$ Children in rural and remote areas, therefore, remained beyond the reach of many of state-directed schemes.

When governments devolved power to villagers to draw up and execute initiatives to school their own children, this power did not fall evenly on the population. Communities with capital - economic and cultural - would have been better able to mobilise to educate their children. Those with experience of education would have been more likely to have ideas about what the local school ought to achieve. Those with means, from spare land and vacant buildings, to donations for school supplies and equipment, would have been able to deploy these resources to build the facilities necessary. Those with government connections and knowledge of the working of the bureaucracy would have been able to tap into programmes of government assistance. The most marginalised, the poorest communities, the most inaccessible, may not have lacked the 'urge', but they may have lacked resources to turn their ideas into reality.

Even for reasonably well-connected communities with sufficient resources, relying on local initiative may have reinforced existing inequalities. It was widely acknowledged that the hierarchies of the caste system remained an integral part of life in postcolonial India. Therefore, it is not at all clear that community efforts would have been aimed at levelling local inequalities. If the local landed elite provided a building for the school, it is conceivable that they would have also been able to dictate whose children could attend classes in that building, and whose children would have to listen to lessons from outside. ${ }^{104}$ When families with food to spare donated it to provide midday meals to those without, the relative social positions of their children would have been reinforced. There is so

\footnotetext{
${ }^{99}$ Report of the Committee to Look into the Causes for Lack of Public Support Particularly in Rural Areas for Girls Education, 11-18.

100 Other Backward Classes were not Dalits, but were still regarded as 'socially and educationally backward'. Report of the Backward Classes Commission, 2. On barrier to education for these groups, see 107-8.

${ }^{101}$ Ojha, Progress of Compulsory Education in India, 229.

102 Ibid., 262, 266.

103 Ibid., 229.

${ }^{104}$ Shailaja Paik, Dalit Women's Education in Modern India: Double Discrimination (Abingdon: Routledge, 2014), 205.
} 
much that historians do not know about how this system of local initiative worked. Even if it was pursued under the broad banner of Indian socialism, however, it would be folly to assume it helped create a more equal society.

\section{Conclusion}

By the end of the period an overwhelming sense of failure had descended upon educationalists. In the centre and in the states there had been innumerable committees, commissions and advisory bodies issuing endless reports. The challenges were clearly mapped out. And yet, as the Kothari Commission noted in 1966, 'a wide and distressing gulf continues to persist between thought and action. ${ }^{105}$ Nearly every aspect of the educational system was disappointing to those who surveyed it. Teacher training remained 'with a few exceptions either mediocre or poor'. ${ }^{106}$ After ten years of experience with pre-school education in rural areas, the Child Welfare Board of the Central Social Welfare Board concluded that, 'many individuals and organizations are not able to start Balwadis on adequate lines, not necessarily because they do not have the resources for it, but because of lack of knowledge of the subject'. ${ }^{107}$ In terms of primary education, India had failed to meet the Constitutional Directive of providing free, universal education up to the age of fourteen by 1960 . Although enrolment had increased, attrition rates were high. Across India, for every 100 students who entered school, only about half reached Class IV, and only $34 \%$ reached class VII. The biggest drop was between year I and year II, where more than $40 \%$ of students dropped out. ${ }^{108}$ Although universities churned out greater numbers of graduates, their unemployment fed anxieties about the adequacies of the education system as a whole. Although India had improved its literacy rate from $16.6 \%$ in 1951 to an estimated 24\% in 1966, the absolute number of illiterate people in India was rising because of population growth. In those fourteen years, India had added $41 \mathrm{~m}$ people to the ranks of the illiterate in the country. ${ }^{109}$ The more cynical were 'beginning to suspect that politicians have a vested interest in illiteracy. ${ }^{110}$

When it came to the great nationalist venture, Basic Education, the Union Education Minister, K.L. Shrimali despaired in 1962, 'basic education has been a failure and I shall not hesitate to confess it. ${ }^{111}$ In Maharashtra, where Basic Education had been pursued enthusiastically at the state level, an enquiry committee admitted that the work done on this national project had been 'not quite satisfactory. ${ }^{\prime 12}$ Half the schools in the state were single-teacher schools, and as a rule, these teachers had had no training, making their conversion to the basic curriculum nominal. ${ }^{113}$ Moreover, it had proved impossible to devise a syllabus that accorded with the high ideals of Basic Education and was also realistic for teachers and students. ${ }^{114}$

Even if they were regarded internally as a failure, these early experiments in education in postcolonial India give us insight into the nature of the postcolonial state and its priorities. Firstly, it

\footnotetext{
${ }^{105}$ Report of the Education Commission (1964-66), 488.

106 Ibid. 67-8.

107 Child Welfare Board, Central Social Welfare Board, Organization of a Rural Balwadi (Nilokheri: Government of India Press, 1964), i.

108 Report of the Education Commission (1964-66), 151,155.

${ }^{109}$ Singh, 'A Review of Work Done in Eradicating Illiteracy', 26.

${ }^{110}$ Deshmukh, Free But Fettered, 19, quoting the Education Commission.

${ }^{111}$ Shrimali, Education in Changing India, 254.

112 Government of Maharashtra, Report of the Basic Education Review Committee, 61.

113 Ibid., 28

114 Ibid., 33.
} 
is important to see this period as a time of uncertainty and flux. ${ }^{115}$ Although India had a stable government at the centre led by Jawaharlal Nehru for 17 years, this was still a period in which Indians were searching for novel solutions to old problems, especially in the field of education. New ideas bubbled up from below and filtered across international networks. They were debated on paper and in assemblies, and they were tested and evaluated in the field. The over-riding feature of the period, therefore, was not so much stability as experimentation.

Secondly, it is still common in the scholarship to regard early independent India as socialist. India may have been aiming at a 'socialistic pattern of society,' ${ }^{116}$ but its means of achieving this aim were far removed from the socialisms of Europe, East or West. Indian policy-makers recognised that education, health, housing, pensions and other parts of the welfare state were essential to the socialist project. But this was a socialism of scarcity. As such, it was built more on self-help than on state-directed institution building or social engineering.

This bottom-up socialism would have increased inequality in India. India's DIY version of socialism relied on local communities to build upon their own capital, whether financial or cultural. As such, those with greater means would have been well-placed to enhance their position through these government-sponsored self-help schemes. This would not only have increased economic differences within the population, it would also have further entrenched the cultural norms and practices that underpinned India's material inequality.

All of this has important consequences for the way we ought to study education in postcolonial India. Although there were innumerable commissions, committees and advisory boards established at the highest echelons of government, the only way we might begin to get a full and textured picture of education in all its variety is from the bottom up.

\footnotetext{
${ }^{115}$ William Gould, Taylor C. Sherman, Sarah Ansari, 'The Flux of the Matter: Loyalty, Corruption and the Everyday State in the Post-Partition Government Services of India and Pakistan, Past and Present 291:1 (2013), 237-279.

${ }^{116}$ Congress Resolution at Avadi, 1955. See, Jawaharlal Nehru, Nehru on Socialism: Selected Speeches and Writings (New Delhi: Perspective Publications, 1964), 105.
} 